\title{
REKONSTRUKSI PERMA No. 1 TAHUN 2016 SEBAGAI ALTERNATIF PENYELESAIAN SENGKETA DI PENGADILAN (Studi Kasus Pengadilan Negeri Simalungun)
}

\author{
Mariah S.M. Purba \\ Fakultas Hukum Universitas Simalungun \\ mariapurba777@gmail.com
}

\begin{abstract}
Law enforcement does not only happen through the judicial process (pro justitia). More just law enforcement can be found through peace, one of which is through alternative dispute settlement, this practice is growing because it is not expensive, and takes a long time. The result (output) not lose or win (win lost solution). In the alternative dispute resolution is a win-win solution. It has long been evolving the idea to seek the choice of dispute resolution mechanism other than through the litigation path that is the alternative of dispute settlement, one of which is mediation. To integrate mediation in civil proceedings law in the Court of First Instance, the Supreme Court issued Supreme Court Regulation no. 02 of 2003 on Mediation Procedures at the Court, then renewed by Supreme Court Regulation no. 1 of 2008 and the last published Regulation of the Supreme Court. 1 of 2016. But with the issuance of Supreme Court Regulation no. 1 of 2016 still found weakness or incompleteness of the rule of law so it is deemed necessary to be reconstructed again.
\end{abstract}

Keywords: Reconstruction, Supreme Court Regulation No. 1 Year 2016, Court.

\begin{abstract}
Abstrak, Penegakan hukum tidak hanya terjadi melalui proses peradilan (pro justitia). Penegakan hukum yang lebih berkeadilan dapat kita temui melalui perdamaian,, salah satunya melalui penyelesaian sengketa alternatif, praktik ini makin berkembang karena tidak mahal, dan memakan waktu yang lama. Hasilnya (out put) bukan kalah atau menang (win lost solution). Dalam penyelesaian sengketa alternatif yang dituju adalah win-win solution. Telah lama berkembang pemikiran untuk mencari pilihan mekanisme penyelesaian sengketa selain melalui jalur litigasi yaitu alternatif penyelesaian sengketa, salah satunya adalah mediasi. Untuk mengintegrasikan mediasi dalam hukum acara perdata di Pengadilan tingkat pertama, Mahkamah Agung menerbitkan PERMA No. 02 Tahun 2003 tentang Prosedur Mediasi di Pengadilan, kemudian diperbaharui dengan PERMA No. 1 Tahun 2008, dan terakhir diterbitkan PERMA No. 1 Tahun 2016. Namun dengan terbitnya PERMA No. 1 Tahun 2016 masih diketemukan kelemahan atau ketidaklengkapan aturan hukum tersebut sehingga dipandang perlu untuk direkonstruksi kembali.
\end{abstract}

Kata Kunci: Rekonstruksi, Perma No. 1 Tahun 2016, Pengadilan

\section{Pendahuluan}

Satu persoalan besar yang sedang dihadapi bangsa kita adalah dilema yang terjadi di bidang penegakan hukum. Disatu sisi kualitas dan kuantitas sengketa yang terjadi didalam masyarakat cenderung mengalami peningkatan dari waktu kewaktu. Sedangkan 
disisi lain, pengadilan negara yang memegang kewenangan mengadali menurut undangundang mempunyai kemampuan yang relatif terbatas, sehingga dari kondisi tersebut terjadilah penumpukan perkara, yang menyebabkan penunggakan perkara di tingkat Mahkamah Agung.

Sejak tahun 2003 Mahkamah Agung telah berupaya mengurangi penumpukan perkara dengan menerbitkan PERMA No. 2 tahun 2003 tentang Prosedur Mediasi di Pengadilan. Kemudian karena dianggap kurang sempurna maka PERMA tersebut disempurnakan lagi dengan terbitnya PERMA No. 1 tahun 2008. Tahun 2016 Peraturan Mahkamah Agung tentang Prosedur Mediasi di Pengadilan telah terbit menggantikan Peraturan Mahkamah Agung No.1 tahun 2008. Diharapakan dengan terbitnya Perma No. 1 Tahun 2016 tersebut dapat menjawab kelemahan-kelemahan Perma No. 1 Tahun 2008. Mediasi efektif karena prosesnya lebih cepat dan murah, serta memberikan akses kepada para pihak yang bersengketa untuk memperoleh keadilan. Keberhasilan mediasi sebagai salah satu alternatif penyelesaian sengketa di Pengadilan sangat dibutuhkan oleh masyarakat pencari keadilan, disamping untuk mengurangi penumpukan perkara yang terjadi.

Dengan menyelesaikan sengketa secara mediasi sekurang-kurangnya ada delapan (8) keuntungan yang diperoleh, yaitu: ${ }^{1}$

a. Untuk mengurangi kemacetan dan penumpukan perkara (court congestion) dilembaga peradilan. Banyaknya kasus yang diajukan ke pengadilan menyebabkan proses pengadilan sering kali berkepanjangan dan memakan biaya yang tinggi serta memberikan hasil yang kurang memuaskan.

b. Untuk meningkatkan keterlibatan masyarakat atau memberdayakan pihak-pihak yang bersengketa dalam proses penyelesaian sengketa.

c. Untuk memperlancar jalur keadilan (acces to justice) di masyarakat.

d. Untuk memberikan kesempatan bagi tercapainya penyelesaian sengketa yang mengahasilkan keputusan yang dapat diterima oleh semua pihak (win-win solution)

e. Penyelesaian sengketa lebih cepat dan murah.

f. Bersifat tertutup/rahasia (confidential).

g. Lebih tinggi tingkat kemungkinan untuk melaksanakan kesepakatan, sehingga hubungan pihak-pihak yang bersengketa dimasa depan masih dimungkinkan terjalin dengan baik.

Selain sebagai salah satu intstrumen efektif dalam mengatasi masalah penumpukan perkara dipengadilan dan sekaligus memperkuat dan memaksimalkan fungsi lembaga pengadilan dalam penyelesaian sengketa, pengaturan institusionalisasi mediasi kedalam proses perkara di pengadilan sebagai upaya pelembagaan dan pendayagunaan mediasi dalam sistim peradilan, sehingga dapat mendorong para pihak menempuh proses perdamaian dalam proses penyelesaian sengketannya. Hal ini sejalan dengan prinsip penyelesaian sengketa yang cepat, murah, yang pada akhirnya dapat memberikan akses

${ }^{1}$ Golberg, F. Sander, and N.H. Rogers. Dispute Resolution: Negotiation, Mediation, and Ather Process (Boston Toronto. Little Brown and Company, 1992) hal. 8 
yang lebih besar kepada para pihak untuk menemukan penyelesaian sengketanya secara memuaskan dan memenuhi rasa keadilan².

Para pihak yang bersengketa akan merasa lebih adil jika sengketa yang mereka hadapi selesai dengan perdamian. Hal ini disebabkan, biasanya perdamaian atas sengketa tersebut berasal dari para pihak yang bersengketa bukan dari pihak lain, sehingga para pihak merasa perdamian tersebut sudah memiliki rasa keadailan bagi pihak masingmasing. Disamping itu hal yang paling penting adalah hubungan kekeluargaan atau kekerabatan atau pertemanan kedepannya bagi para pihak jauh lebih baik apabila sengketa yang mereka hadapi dapat diselesaiakan dengan perdamaian dibandingkan dengan putusan hakim. Hal ini disebabkan kesepakatan yang diambil oleh para pihak bersiaf win-win solution bukan bersifat win lost solotion.

Biasanya para pihak yang bersengketa di pengadilan yang sengketanya diputus dengan putusan hakim mengakibatkan hubungan para pihak akan jauh lebih buruk, sebab terdapat keadudukan menang disatu pihak dan kalah dipihak lain. Namun, pada kenyatannya sejak diberlakukannya PERMA No. 1Tahun 2016 hingga saat ini belum ada sengketa yang berhasil diselesaikan dengan mediasi. Kegagalan meadiasi tersebut disebabkan beberapa faktor antara lain: faktor peraturan dala hal ini PERMA No. 1 tahun 2016 masih kurang lengkap, disamping faktor lain misalnya peran mediator masih kurang maksimal. Kurang maksimalnya peran mediator tersebut bukan karena waktu yang sempit, tetapi lebih dikarenakan profesionalisme yang kurang memadai. Disamping itu ketidak berhasilan mediasi juga dikarenakan para pihak yang belum memahami keuntungan dan kerugian apabila sengketa tersebut diselesaiakan melalui mediasi, dan pengaruh atau peran advokat yang menjadi kuasa atas sengketa tersebut.

Perubahan paradigma mengadili menjadi paradigma penyelesaian masalah atau sengketa hukum adalah merupakan suatu strategi yang dapat mendorong berkembangnya penyelesaian sengketa di luar proses peradilan baik yang dilekatkan pada pengadilan atau diluar pengadilan. Paradigma baru ini akan mencakup 4 (empat) strategi pokok, yaitu

1. Revitalisasi fungsi pengadilan untuk mendamaikan pihak-pihak yang menghadapi sengketa hukum..

2. Revitalisasi pranata-pranata sosial dengan memberikan dasar-dasar yang lebih kuat bagi pengembangan lembaga penyelesaian alternatif seperti arbitrase, mediasi dan lain-lain. Selain itu perlu didorong peran-peran lain seperti lembaga bantuan hukum untuk mediasi dan lain-lain.

3. Menata kembali tata cara penyelesaian suatu perkara menjadi lebih efisien, efektif, produktif, dan mencerminkan keterpaduan sistim diantara unsur-unsur penegak hukum dengan merinci pembagian tugas dan wewenang yang tegas diantara para penegak hukum.

4. Menata kembali hak-hak berperkara yang menyebabkan penyelesaian yang berlarut-larut, dan mengandung potensi konflik permanen diantara pihak-pihak atau mereka yang berperkara. Starategi ini berkaitan dengan pembatasan hak kasasi yang dapat didasarkan kepada nilai perkara, ancaman pidana atau sifat

2 Rachmadi Usman. 2012. Mediasi Di Pengadilan Dalam Teori dan Praktek. Jakarta. Sinar Grafika. Hal. Viii. 
perkara. Yang terakhir ini berkaitan dengan perkara-perkara di bidang (hukum) kekeluargaan (perceraian, pemeliharaan anak, pengangkatan anak, harta perkawinan dan lain-lain). Pembatasan hak kasasi pada perkara-perkara (hukum) kekeluargaan dimaksudkan agar dapat tuntas secepat mungkin mengingat kepentingan-kepentingan dari pihak dan orang ketiga (seperti anak) yang bersangkutan dalam perkara tersebut.

Dari latar belakang tersebut dapat ditarik bebarapa permasalahan. Adapun permasalahan yang akan diteliti dalam penelitian ini adalah:

a. Mengapa mediasi sebagai alternatif Penyelesaikan sengketa perdata di Pengadilan saat ini belum efektif?.

b. Bagaimana rekonstruksi PERMA No. 1 Tahun 2016 sebagai alternatif penyelesaian sengketa di Pengadilan?

\section{Pembahasan}

Dalam terminologi hukum, istilah mediation berarti pihak ketiga yang ikut campur dalam perkara yang cenderung mencari penyelesaiannya. ${ }^{3}$ Sedangkan pihak yang menjadi penengah disebut dengan istilah "mediator". Gary Goodpaster dalam bukunya menyatakan bahwa mediasi adalah proses negosiasi pemecahan masalah di mana pihak luar yang tidak memihak/impartial dan netral bekerja dengan pihak yang bersengketa untuk membantu mereka memperoleh kesepakatan perjanjian dengan memuaskan (perdamaian).yang berarti berada di tengah karena seorang yang melakukan mediasi (mediator) harus berada di tengah orang yang berikai ${ }^{5}$.

Setelah diberlakukan PERMA No. 1 Tahun 2016 sangat diharapkan untuk mengurangi penunggakan perkara dan pemenuhan rasa keadilan yang cepat, tepat, sederhana dan murah dipihak berperkara. Namun seperti yang kemukan diatas bahwa ternyata PERMA No. 1 tahun2016 tersebut hingga saat ini belum berhasil menyelesaikan sengketa dengan mediasi, dimana salah satu penyebabnya adalah PERA No. 1 Tahun 2016 tersebut masih kurang lengkap.

Menurut Lawrence Meir Friedman ${ }^{6}$ berhasil atau tidaknya Penegakan hukum bergantung pada: substansi hukum, stuktur hukum, dan budaya hukum. Yang dimaksud dengan substansial adalah hal yang menentukan bisa atau tidaknya hukum itu dilaksanakan. Substansi juga berarti produk yang dihasilkan oleh orang yang berada dalam sistem hukum yang mencakup keputusan yang mereka keluarkan, aturan baru yang mereka susun. Substansi juga mencakup hukum yang hidup (living law), bukan hanya aturan yang ada dalam kitab undang-undang (law books).

Dari segi substansi, hasil penelitian yang dilakukan membuktikan bahwa mediasi belum berhasil mengurangi penumpukan perkara. Dengan perkataan lain pelaksanaan mediasi sebagai alternatif penyelesaian sengketa belum berhasil, baik untuk mengurangi

${ }^{3}$ I.P.M. Ranuhandoko. Terminologi Hukum Inggris Indonesia, Cetakan ke 4. Jakarta: Sinar Grafika . Hal . 339

${ }^{4}$ Ibid

${ }^{5}$ Gary Goodpaster, Negosiasi dan Mediasi: Sebuah Pedoman Negosiasi dan Penyelesaian Sengketa Melalui Negosiasi, (Jakarta: ELIPS Project, 1993).

${ }^{6}$ W. Friedman, Legal Teori, (New York: Colombia Universiti Press, 1967) 
penumpukan perkara maupun untuk memenuhi rasa keadilan sebab rasa keadilan akan terpenuhi jika sengketa itu diselesaikan secara damai melalui mediasi, bukan penyelesaian melalui litigasi.

Ketidak berhasilan PERMA No. 1 Tahun 2016 salah satu penyebabnya adalah ketentuan-ketentuan yang ada di dalam PERMA tersebut kurang sempurna, atau PERMA tersebut belum mengatur ketentuan mediasi lebih rinci dan lengkap, misalnya: tidak adanya insentif bagi mediator hakim, sedangkan mediator yang bukan hakim mendapat insentif sesuai dengan kesepakatan para pihak. Hal ini menyebabkan ada kecenderungan mediator hakim kurang serius dan maksimal dalam mengupayakan mediasi. Meskipun dalam Pasal 16 menyebutkan bahwa Ketua Pengadilan wajib menyampaikan laporan kinerja hakim atau pegawai pengadilan yang berhasil menyelesaikan perkara melalui mediasi kepada Ketua Pengadilan Tinggi dan mahkamah Agung, tanpa secara tegas menyebukan award apa yang akan diperoleh oleh mediator hakim atau pegawai pengadilan atas keberhasilannya tersebut. peraturan ini juga tidak ada mengatur bagi hakim mediator atau pegawai pengadilan yang tidak pernah berhasil menyelesaikan perkara melalui mediasi. Dengan tidak adanya aturan tersebut menyebabkan tidak adanya kewajiban bagi hakim mediator atau pegawai pengadilan untuk menyelesaikan sengketa dengan mediasi.

Namun disisi lain, sesuai dengan hasil penelitian, tidak ada satu perkarapun di Pengadilan Negeri Simalungun yang mempergunakan jasa mediator di luar pengadilan. Hal ini disebabkan adanya beban biaya yang ditanggung oleh para selain biaya kepengadilan apabila para pihak menggunakan jasa mediator di luar pengadilan. Sehingga perlu dipertimbangkan agar negara memberikan insentif kepada mediasi di luar pengadilan yang berhasil didamaikan oleh mediator. Hal ini cukup beralasan karena negara juga memberikan bantuan hukum kepada masyarakat dalam mencarai keadilan baik dalam perkara perdata dan pidana. Dengan berhasilnya para pihak menyelesaikan sengketanya melalui mediasi berarti masyarakat yang mencari keadilan telah menemukannya.

Dari segi Struktural, yaitu yang menentukan dapat atau tidaknya hukum itu dilaksanakan dengan baik. Struktur hukum Dalam PERMA No. 1 Tahun 2016 meliputi para pihak, mediator dan advokad.

Kurangnya pemahaman para pihak terhadap mediasi adalah merupakan faktor utama gaglnya meadiasi. Ada kecenderungan bagi para pihak yang berperkara untuk memiliki objek sengketa. Para pihak enggan untuk memperoleh konpensasi atas perkara tersebut. Kurangnya pengetahuan para pihak tentang keuntungan dan kebaikan penyelesaian sengketa melalui mediasi adalah merupakan salah satu penyebab gagalnya mediasi.

Itikad baik sangat penting guna keberhasilan proses mediasi agar terjadi kesepakatan yang win win solution. Apabila para pihak tidak mau melihat kebutuhan mereka dan hanya mengejar keuntungan, maka perdamaian melalui mediasi akan sulit tercapai. Tetapi biasanya itikad baik para pihak tidak ada dikarenakan para pihak masih kurang mengerti mengenai mediasi dan apa manfaat mediasi bagi mereka, serta apa akibat hukumnya jika sengketa tersebut diselesaikan secara mediasi atau diselesaikan secara litigasi. Hal lain yang perlu diutarakan kepada para pihak adalah hubungan baik 
kedepan antara para pihak akan lebih baik jika sengketa tersebut diselesaikan melalui mediasi, karena dalam penyelesaian secara mediasi tidak ada pihak yang dikalahkan atau pihak yang dimenangkan. Sengketa tersebut diselesaikan secara musyawarah dengan menganulr kehendak para pihak.

Dari sisi mediator, masih kurangnya tenaga mediator hakim yang bersertifikat merupakan kendala keberhasilan mediasi. Mediator yang handal dan memiliki kemauan untuk mengakhiri sengketa dengan mediasi sangat dibutuhkan dalam berhasilnya mediasi. Kurangnya mediator hakim yang bersertifikasi juga menjadi kendala ${ }^{7}$. Kemampuan mediator yang handal memang sangat dibutuhkan dalam melakukan mediasi.

Jumlah mediator hakim bersertifikat yang terbatas mempengaruhi pula pelaksanaan mediasi di pengadilan, pada hal jumlah perkara perdata yang diajukan ke pengadilan terbilang banyak dan memerlukan mediator. Sampai saat ini jumlah mediator yang terdaftar di pengadilan masih sangat sedikit. Oleh karena itu guna pemberdayaan PERMA tersebut maka jumlah tenaga mediator haru ditingkatkan yang diikuti pula oleh lembaga penyedia jasa mediator. Selain itu dalam praktek hakim mediator sering tidak melaksanakan Tahapan Tugas Mediator sebagaimana diatur dalam Pasal 14 PERMA No. 1 Tahun 2016.

Budaya Hukum atau Kultur hukum menurut Lawrence Meir Friedman adalah sikap manusia terhadap hukum dan sistem hukum, kepercayaan, nilai, pemikiran, serta harapannya. Kultur hukum adalah suasana pemikiran sosial dan kekuatan sosial yang menentukan bagaimana hukum digunakan, dihindari, atau disalahgunakan. Budaya hukum erat kaitannya dengan kesadaran hukum masyarakat. Semakin tinggi kesadaran hukum masyarakat maka akan tercipta budaya hukum yang baik dan dapat merubah pola pikir masyarakat mengenai hukum selama ini. Secara sederhana, tingkat kepatuhan masyarakat terhadap hukum merupakan salah satu indikator berfungsinya hukum.

Hubungan antara tiga unsur sistem hukum itu sendiri tak berdaya, seperti pekerjaan mekanik. Struktur diibaratkan seperti mesin, substansi adalah apa yang dikerjakan dan dihasilkan oleh mesin, sedangkan kultur hukum adalah apa saja atau siapa saja yang memutuskan untuk menghidupkan dan mematikan mesin itu, serta memutuskan bagaimana mesin itu digunakan. Dikaitkan dengan sistem hukum di Indonesia, Teori Friedman tersebut dapat kita jadikan patokan dalam mengukur proses penegakan hukum di Indonesia. Para pihak bagian dari struktur bersama dengan mediator, dan advokat. Walau demikian, tegaknya hukum tidak hanya ditentukan oleh kokohnya struktur, tetapi juga terkait dengan kultur hukum di dalam masyarakat. Kesemuanyaitu sangat berpengaruh terhadap efektivitas kinerja sebuah hukum. Dari beberapa definisitersebut, dapat diartikan bahwa berfungsinya sebuah hukum merupakan pertanda bahwa hukum tersebut telah mencapai tujuan hukum, yaitu berusaha untuk mempertahankan dan melindungi masyarakat dalam pergaulan hidup. Tingkat efektivitas hukum juga ditentukan oleh seberapa tinggi tingkat kepatuhan warga masyarakat terhadap aturan hukum yang telah dibuat.

\footnotetext{
${ }^{7}$ Bandingkan dengan PERMA No. 1 tahun 2016 Pasal 13 dan 14
} 
Memang Perma No. 1 Tahun 2016 telah mengalami beberapa perubahan dibanding dengan Perma No. 1 Tahun 2008. Dimana perubahan tersebut diharapkan kearah yang lebih dibanding Perma sebelumnya.

Dibawah ini dijelaskan beberapa perbedaan antara PERMA No. 1 Tahun 2008 dengan PERMA No. 1 Tahun 2016

Tabel 1: Perbedaan PERMA No. 1 Tahun 2008 dengan PERMA No. 1 Tahun 2016

\begin{tabular}{|c|c|c|}
\hline No & PERMA No. 1 Tahun 2008 & PERMA No. 1 Tahun 2016 \\
\hline 1 & Terdiri dari 27 (dua puluh tujuh) pasal & $\begin{array}{l}\text { Terdiri dari } 39 \text { (tiga puluh sembilan) } \\
\text { pasal }\end{array}$ \\
\hline 2 & $\begin{array}{lllr}\text { Belum diatur pemakaian teknologi } \\
\text { audio visual jarak jauh dalam } \\
\text { pelaksanaan mediasi. }\end{array}$ & $\begin{array}{l}\text { Sudah diatur ketentuan pemakaian } \\
\text { teknoligi audio visual jarak jauh } \\
\text { dalam pelaksanaan mediasi (Pasal } 6 \\
\text { ayat (2). }\end{array}$ \\
\hline 3 & $\begin{array}{l}\text { Belum diatur terhadap perkara yang } \\
\text { tidak dilakukan mediasi apabila } \\
\text { diajukan upaya hukum banding atau } \\
\text { kasasi tidak ada perintah oleh } \\
\text { Pengadilan Tinggi atau Mahkamah } \\
\text { Agung kepada pengadilan tingkat } \\
\text { pertama untuk melakukan proses } \\
\text { mediasi. }\end{array}$ & $\begin{array}{l}\text { Sudah diatur terhadap perkara yang } \\
\text { tidak dilakukan mediasi apabila } \\
\text { diajukan upaya hukum, maka ada } \\
\text { perintah dari pengadilan tingkat } \\
\text { banding atau kasasi kepada } \\
\text { pengadilan tingkat pertama untuk } \\
\text { melakukan proses mediasi (Pasal } 3 \\
\text { ayat (4). }\end{array}$ \\
\hline 4 & $\begin{array}{l}\text { Putusan terhadap perkara yang tidak } \\
\text { menempuh mediasi adalah Batal Demi } \\
\text { Hukum (Pasal } 2 \text { ayat (3) }\end{array}$ & $\begin{array}{l}\text { Putusan terhadap perkara yang tidak } \\
\text { menempuh mediasi (akibat kelalaian } \\
\text { Hakim Pemeriksa) tidak ada. }\end{array}$ \\
\hline 5 & $\begin{array}{l}\text { Meditor yang berasal dari pengadilan } \\
\text { hanyalah hakim yang telah memiliki } \\
\text { sertifikat mediatorr }\end{array}$ & $\begin{array}{l}\text { Mediator yang berasal dari dalam } \\
\text { pengadilan selain hakim juga } \\
\text { pegawai pengadilan yang memiliki } \\
\text { sertifikat mediator (Pasal 8) }\end{array}$ \\
\hline 6 & $\begin{array}{l}\text { Proses mediasi berlangsung paling lama } \\
40 \text { (empat puluh( hari kerja) sejak } \\
\text { memilih mediator, atas kesepakatan } \\
\text { para pihak, jangka waktu mediasi dapat } \\
\text { diperpanjang paling lama } 14 \text { (empat } \\
\text { belas) hari kerja sejak berakhirnya masa } \\
40 \text { (empat puluh) hari (Pasal } 13 \text { ayat ( } 3 \\
\text { dan 4)). }\end{array}$ & $\begin{array}{l}\text { Proses mediasi berlangsung paling } \\
\text { lama } 30 \text { (tiga puluh( hari kerja) sejak } \\
\text { memilih mediator, atas kesepakatan } \\
\text { para pihak, jangka waktu mediasi } \\
\text { dapat diperpanjang paling lama } 30 \\
\text { (tiga puluh) hari kerja, dan masih } \\
\text { dapat diperpanjang kembali } \\
\text { berdasarkan permintaan para pihak } \\
\text { (Pasal } 24 \text { ayat. }\end{array}$ \\
\hline 7 & $\begin{array}{l}\text { Dalam proses mediasi jika dianggap } \\
\text { perlu dapat dimintakan keterlibatan } \\
\text { ahli }\end{array}$ & $\begin{array}{l}\text { Dalam proses mediasi jika diangap } \\
\text { perlu dapat dimintakan keterlibatan } \\
\text { selain ahli juga tokoh masyarakat, } \\
\text { tokoh agama dan tokoh adat (Pasal } \\
\text { 26). }\end{array}$ \\
\hline
\end{tabular}




\begin{tabular}{|l|l|l|}
\hline 8 & $\begin{array}{l}\text { Terhadap pihak penggugat yang tidak } \\
\text { beritikad baik dalam melaksanakan } \\
\text { mediasi akibatnya terhadap gugatan } \\
\text { tidak ada. }\end{array}$ & $\begin{array}{l}\text { Terhadap pihak penggugat yang } \\
\text { tidak beritikad baik dalam } \\
\text { melaksanakan mediasi akibatnya } \\
\text { terhadap gugatan adalah gugatan } \\
\text { dinyatakan tidak dapat diterima } \\
\text { (pasal 22 ayat 1). }\end{array}$ \\
\hline 9 & $\begin{array}{l}\text { Tidak mengenal kesepakatan } \\
\text { perdamaian sebahagian atas sengketa }\end{array}$ & $\begin{array}{l}\text { Mengenal kesepakatan perdamian } \\
\text { sebahagian atas sengketa (Pasal 29). }\end{array}$ \\
\hline 10 & $\begin{array}{l}\text { Ketua pengadilan tidak berperan dalam } \\
\text { menyampaikan kinerja hakim } \\
\text { pengadilan yang } \\
\text { menyelesaikan perkara melalui mediasi } \\
\text { kepada Ketua Pengadilan Tinggi dan } \\
\text { Ketua Mahkamah Agung. }\end{array}$ & $\begin{array}{l}\text { Ketua pengadilan } \\
\text { menyampaikan kinerja hakim dan } \\
\text { pegawai pengadilan yng berhasil } \\
\text { menyelesaikan perkara melalui } \\
\text { mediasi kepada Ketua Pengadilan } \\
\text { Tinggi dan Ketua Mahkamah Agung } \\
\text { (Pasal 16). }\end{array}$ \\
\hline 11 & $\begin{array}{l}\text { Tidak mengatur pihak Tergugat yang } \\
\text { tidak beritikad baik yang menanggung } \\
\text { biaya mediasi. }\end{array}$ & $\begin{array}{l}\text { Sudah mengatur pihak Tergugat } \\
\text { yang tidak beritikad baik yang } \\
\text { menanggung biaya mediasi (Pasal } \\
\text { 23). }\end{array}$ \\
\hline 12 & $\begin{array}{l}\text { Para pihak atau kuasa hukumnya tidak } \\
\text { diwajibkan menandatangani surat yang } \\
\text { menerangkan bahwa Majelis Hakim } \\
\text { pertama manfaat mediasi pada saat sidang }\end{array}$ & $\begin{array}{l}\text { Para pihak atau kuasa hukumnya } \\
\text { wajiib menandatangani surat yang } \\
\text { menerangkan bahwa majelis hakim } \\
\text { pemeriksa telah menjelaskan } \\
\text { prosedur dan manfaat mediasi pada } \\
\text { saat sidang pertama (Pasal 17 ayat } \\
(9) .\end{array}$ \\
\hline
\end{tabular}

Beberapa perubahan-perubahan yang terdapat pada Perma No. 1 Tahun 2016 sudah menjawab kekurangan yang ada pada Perma sebelumnya, antara lain, sudah diantisipasi bagi para pihak yang sakit atau berada di luar negeri untuk dapat melaksanakan mediasi dengan cara mempergunakan teknologi yaitu mempergunakan audio visual jarak jauh. Dimana pemakaian audio visual jarak jauh tersebut dianggap sebagai kehadiran langsung. Hal ini tentu sangat membatu para pihak yang berada diluar negeri atau sedang sakit.

Namun ternyaa masih terdapat kelemahan-kelemahan pada Perma No. 1 tahun 2016, kelemahan tersebut antara lain masih kurang jelas, juga terdapat perubahan yang kurang sempurna atau kurang lengkap. Sehingga dipandang perlu untuk merekonstruksi kembali Perma No. 1 Tahun 2016.

Pada PERMA No. 1 tahun 2016 Pasal 3 ayat (3) yang bunyinya: Hakim pemeriksa perkara yang tidak memerintahkan para pihak untuk menempuh mediasi 
sehingga para pihak tidak melakukan mediasi telah melanggar ketentuan peraturan perundang-undangan yang mengatur tentang mediasi di pengadilan. Pada pasal tersebut jelas disebutkan bahwa hakim pemeriksa yang tidak menempuh mediasi telah melanggar ketentuan peraturan perundang-undangan. Namun atas pelanggaran tersebut tidak ada diatur akibat yang harus diterima oleh Hakim Pemerikasa perkara tersebut. Sudah jelas setiap pelanggaran terhadap letentuan perundang-undangan biasanya disertai dengan adanya sanksi. Selain itu pasal ini juga tidak ada mengatur akibat hukum terhadap putusan yang tidak menempuh mediasi. Memang pada ayat (4) menyebutkan : Dalam hal terjadi pelanggaran terhadap ketentuan sebagai mana di maksud dalam ayat (3), apabila diajukan upaya hukum maka pengadilan Tingkat Banding atau Mahkama Agung dengan putusan sela memerintahkan Pengadilan Tingkat Pertama untuk melakukan proses mediasi. Timbul pertanyaan bagaimana jika terhadap putusan tersebut tidak diajukan upaya hukum Banding atau Kasasi? Apakah putusan atas perkara tersebut sah? Jika sah berarti melanggar ketentuan Pasal 4 ayat (1) yang menyatakan: Semua sengketa Perdata yang diajukan ke pengadilan termasuk perkara perlawanan (verzet) atas putusan verstek dan perlawanan pihak berperkara (partij verzet) maupun pihak ketiga (derden verzet) terhadap pelaksanaan putusan yang telah berkekuatan hukum tetap, wajib terlebih dahulu diupayakan penyelesaian melalui mediasi, kecuali ditentukan lain berdasarkan peraturan Mahkaah Agung ini.

Sedangkan Pasal 16 menyebutkan: "Ketua Pengadilan wajib menyampaikan laporan kinerja hakim atau pegawai pengadilan yang berhasil menyelesaiakan perkara melalui mediasi kepada Ketua Pengadilan Tinggi dan Mahkamah Agung",

Pada pasal tersebut jelas disebutkan keberhasilan mediator dalam menyelesaikan perkara tersebut secara mediasi hanya sebatas pelaporan oleh Ketua Pengadilan. Tidak dijelaskan apa yang akan diterima oleh hakim mediator apabila mediator tersebut berhasil melakukan mediasi.Kriteria keberhasilan mediator dapat diukur dari sisi pelaksanaan proses dan dari hasil kepuasan para pihak atas hasil mediasi. Pada pasal ini juga belum mengatur sanksi terhadap hakim mediator yang tidak pernah berhasil melaksanakan mediasi. Jika hal ini tidak diatur tidak menutup kemungkinan bagi hakim mediator untuk serius mengupayakan agar sengketa tersebut berhasil melalui proses mediasi.

Dibawah ini dijelaskan beberapa kelemahan-kelemahan PERMA No. 1 Tahun 2016

Tabel 2: Kelemahan-kelemahan PERMA No. 1 Tahun 2016

\begin{tabular}{|l|l|l|lr|}
\hline NO & $\begin{array}{l}\text { Isi Pasal Sebelum } \\
\text { Rekonstruksi }\end{array}$ & Kelemahan & $\begin{array}{l}\text { Isi Pasal Setelah } \\
\text { Rekonstruksi }\end{array}$ \\
\hline 1 & Pasal 3 ayat (3) Hakim & Dari bunyi Pasal 3 ayat & Pada Pasal 3 ayat (3) \\
& pemeriksa perkara yang & (3) tersebut tersirat bahwa & ditambah rata-kata \\
& tidak memerintahkan para & para pihak tidak & menjadi: & Hakim \\
& pihak untuk menempuh & menempuh r mediasi & pemeriksa perkara \\
& mediasi sehingga para & dikarenakan kelalaian & yang & tidak \\
& pihak tidak melakukan & Hakim Pemeriksa yang & memerintahkan para \\
& mediasi telah melanggar & tidak memerintahkannya. & pihak & untuk \\
\hline
\end{tabular}




\begin{tabular}{|c|c|c|c|}
\hline & $\begin{array}{l}\text { ketentuan peraturan } \\
\text { perundang-undangan } \\
\text { yang mengatur tentang } \\
\text { mediasi pengadilan. } \\
\text { Ayat (4) Dalam hal terjadi } \\
\text { pelanggaran terhadap } \\
\text { ketentuan sebagai mana di } \\
\text { maksud dalam ayat (3), } \\
\text { apabila diajukan upaya } \\
\text { hukum maka pengadilan } \\
\text { tingkat banding atau } \\
\text { mahkama agung dengan } \\
\text { putusan sela } \\
\text { memerintahkan } \\
\text { pengadilan tingkat } \\
\text { pertama untuk melakukan } \\
\text { mediasi. }\end{array}$ & $\begin{array}{l}\text { Namun anehnya terhadap } \\
\text { Hakim Pemeriksa yang } \\
\text { melakukan kelalaian tidak } \\
\text { ada diatur apa akibat yang } \\
\text { akan ditanggungnya. } \\
\text { Namun berbeda dengan } \\
\text { para pihak yang } \\
\text { diwajibkan kembali untuk } \\
\text { menempuh mediasi atas } \\
\text { perkara tersebut apabila } \\
\text { diajukan Banding atau } \\
\text { Kasasi maka Pengadilan } \\
\text { Tinggi Banding atau } \\
\text { Mahkamah Agung } \\
\text { memerintahkan } \\
\text { Pengadilan Tingkat } \\
\text { Pertama untuk melakukan } \\
\text { proses mediasi. Yang } \\
\text { menjadi pertanyaan } \\
\text { adalah bagaimana jika } \\
\text { terhadap putusan tersebut } \\
\text { tidak diajukan upaya } \\
\text { hukum Banding atau } \\
\text { Kasasi. Apakah putusan } \\
\text { itu sah? Jika sah berarti } \\
\text { betentangan dengan Pasal } \\
4 \text { ayat } 1 \text { a }\end{array}$ & $\begin{array}{lr}\text { menempuh } & \text { mediasi } \\
\text { sehingga } & \text { para } \\
\text { tidak } & \text { pelakukak } \\
\text { mediasi } & \text { telah } \\
\text { melanggar } & \text { ketentuan } \\
\text { peraturan } & \text { perundang- } \\
\text { undangan } & \text { yang } \\
\text { mengatur } & \text { tentang } \\
\text { mediasi } & \text { pengadilan, } \\
\text { dikenakan } & \text { sanksi } \\
\text { administrasi, } & \text { yang } \\
\text { jenisnya } & \text { ditentukan } \\
\text { oleh Ketua } & \text { Pengadilan } \\
\text { Tinggi } & \text { atau } \\
\text { Mahkamah Agung. }\end{array}$ \\
\hline 2 & $\begin{array}{l}\text { Pasal } 3 \text { Ayat (4) Dalam } \\
\text { hal terjadi pelanggaran } \\
\text { terhadap ketentuan } \\
\text { sebagai mana di maksud } \\
\text { dalam ayat (3), apabila } \\
\text { diajukan upaya hukum } \\
\text { maka pengadilan Tingkat } \\
\text { Banding atau Mahkama } \\
\text { Agung dengan putusan } \\
\text { sela memerintahkan } \\
\text { Pengadilan Tingkat } \\
\text { Pertama untuk melakukan } \\
\text { proses mediasi. }\end{array}$ & $\begin{array}{l}\text { Yang menjadi pertanyaan } \\
\text { adalah bagaimana jika } \\
\text { terhadap putusan tersebut } \\
\text { tidak diajukan upaya } \\
\text { hukum Banding atau } \\
\text { Kasasi. Apakah putusan } \\
\text { itu sah? Jika sah berarti } \\
\text { betentangan dengan Pasal } \\
4 \text { ayat } 1\end{array}$ & $\begin{array}{lr}\text { Bunyi Pasal } 3 & \text { ayat } 4 \\
\text { ditambahi } & \text { kalimat: } \\
\text { Dalam hal terjadi } \\
\text { pelanggaran terhadap } \\
\text { ketentuan sebagai } \\
\text { mana di maksud dalam } \\
\text { ayat } \\
\text { mengakibatkan } \\
\text { putusan batal demi } \\
\text { huku. Namun apabila } \\
\text { diajukan upaya hukum } \\
\text { maka pengadilan } \\
\text { Tingkat Banding atau } \\
\text { Mahkama Agung } \\
\text { dengan putusan sela } \\
\text { memerintahkan } \\
\text { Pengadilan Tingkat }\end{array}$ \\
\hline
\end{tabular}




\begin{tabular}{|c|c|c|c|}
\hline & & & $\begin{array}{l}\text { Pertama } \\
\text { melakukan } \\
\text { mediasi. }\end{array}$ \\
\hline 3 & $\begin{array}{lr}\text { Pasal 16: } & \text { Ketua } \\
\text { Pengadilan } & \text { wajib } \\
\text { menyampaikan laporan } & \text { kinerja hakim } \quad \text { atau } \\
\text { pegawai pengadilan yang } \\
\text { berhasil menyelesaikan } \\
\text { perkara melalui mediasi } \\
\text { kepada ketua pengadilan } \\
\text { tinggi dan mahkama } \\
\text { agung. }\end{array}$ & 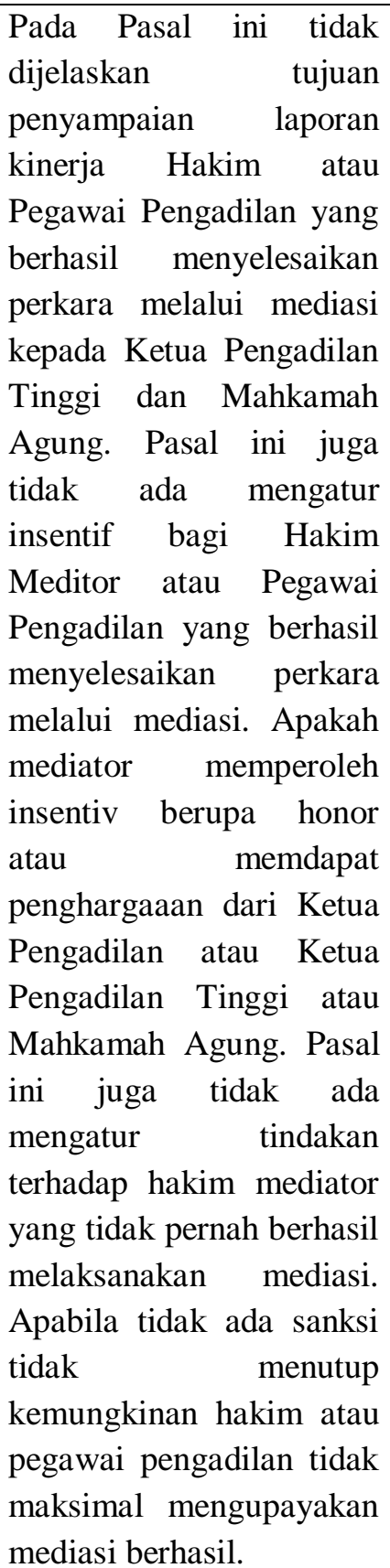 & 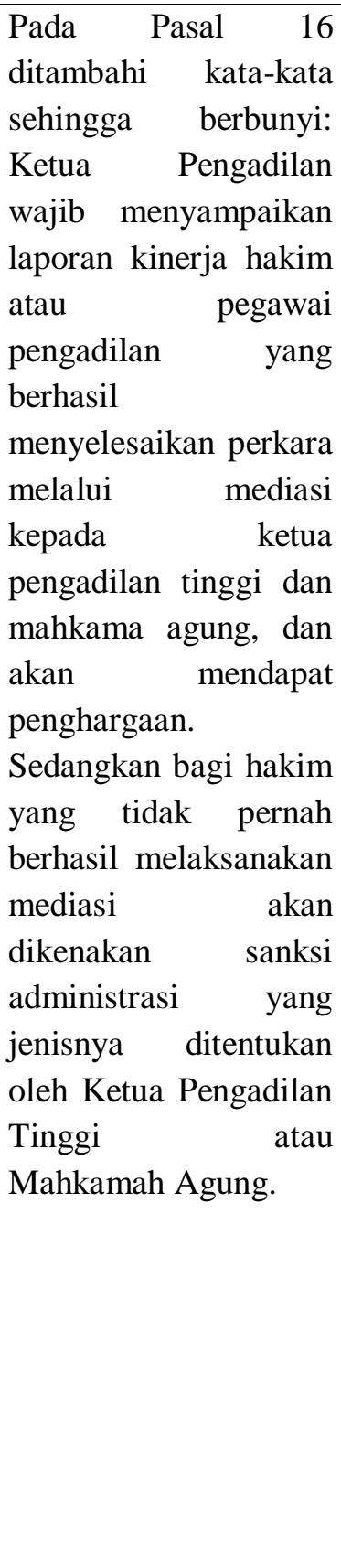 \\
\hline
\end{tabular}

\section{Kesimpulan}

Proses mediasi dalam menyelesaikan perkara perdata di pengadilan masih belum maksimal. Hambatan pelaksanaan mediasi dalam penyelesaian perkara perdata di pengadilan antara lain peraturan yang mengatur belum jelas, lengkap dan tegas. Sehingga menimbulkan belum siapnya para hakim mediator mengupayakan keberhasilan sengketa 
melalui mediasi. Hal ini dikarenakan belum tegasnya aturan terhadap hakim mediator yang tidak pernah berhasil menyelesaikan sengketa melalui mediasi, dan belum tegasnya penghargaan terhadap hakim mediator yang berhasil dalam melaksanakan mediasi.

Untuk lebih memperoleh hasil yang lebih baik dalam pelembagaan mediasi di pengadilan dipandang perlu untuk merekonstruksi PERMA No. 1 Tahun 2016 karena masih terdapat bebarapa hal yang belum diatur yang dipandang sangat berpengaruh terhadap berhasil tidaknya mediasi.

\section{Daftar Pustaka}

Gary Goodpaster, Negosiasi dan Mediasi: Sebuah Pedoman Negosiasi dan Penyelesaian Sengketa Melalui Negosiasi, ELIPS Project, Jakarta, 1993

Golberg, F. Sander, and N.H. Rogers, Dispute Resolution: Negotiation, Mediation, and Ather Process, Boston Toronto. Little Brown and Company, 1992

Rachmadi Usman, Mediasi Di Pengadilan Dalam Teori dan Praktek, Sinar Grafika. Jakarta, 2012

Ranuhandoko. I.P.M., Terminologi Hukum Inggris Indonesia, Cetakan ke 4. Sinar Grafika, Jakarta, 2013

W. Friedman, Legal Teori, New York: Colombia Universiti Press, 1967PERMA No. 1 Tahun 2008

PERMA No. 1 Tahun 2016 tentang Prosedur Mediasi di Pengadilan 